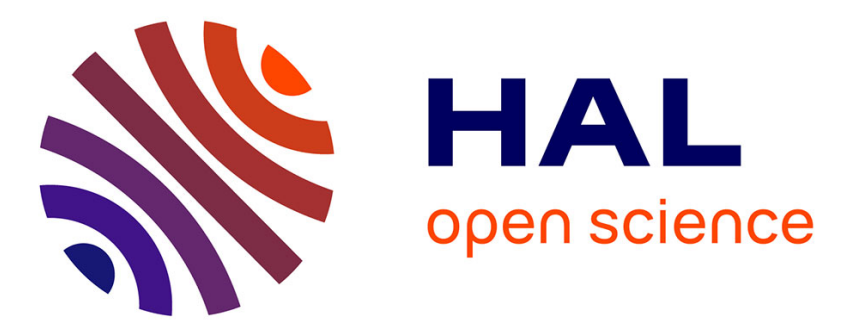

\title{
Time-series Estimates of the Macroeconomic Impact of Defence Spending in France and the UK
}

\author{
Stephen Martin, Ron Smith, Jacques Fontanel
}

\section{To cite this version:}

Stephen Martin, Ron Smith, Jacques Fontanel. Time-series Estimates of the Macroeconomic Impact of Defence Spending in France and the UK. Christian Schmidt; Frank Blackaby. Peace, defence and economic analysis : proceedings of a conference held in Stockholm jointly by the International economic association and the Stockholm international peace research Institute, Palgrave Macmillan, pp.342362, 1987, International Economic Association Series, 0-333-42275-9. 10.1007/978-1-349-18898-7_16 . hal-02937438

\section{HAL Id: hal-02937438 \\ https://hal.univ-grenoble-alpes.fr/hal-02937438}

Submitted on 16 Sep 2020

HAL is a multi-disciplinary open access archive for the deposit and dissemination of scientific research documents, whether they are published or not. The documents may come from teaching and research institutions in France or abroad, or from public or private research centers.
L'archive ouverte pluridisciplinaire HAL, est destinée au dépôt et à la diffusion de documents scientifiques de niveau recherche, publiés ou non, émanant des établissements d'enseignement et de recherche français ou étrangers, des laboratoires publics ou privés. 


\title{
Time-series estimates of the macroeconomic impact of defence spending in France and the UK
}

\author{
Stephen Martin, Ron Smith, Jacques Fontanel
}

\author{
Colloquium International Economic Association \\ Stockholm International Peace Research Institute \\ Stockholm, October 1985 \\ in
}

\author{
Peace, Defence and Economic Analysis" \\ (SCHMIDT C. \& BLACKHABY F., Ed). \\ Mac Millan, London, 1987 (20 pages).
}

Measures of the effect of military expenditure on the economy had tended to rely input-output or international cross-section models than rather time-series estimates. We estimate the effect of military expenditure on investment, employment and growth on France and UK. The main results suggest that military expenditure tends to reduce investment and increase unemployment. It has a positive immediate effect on growth, but when the system feedbacks are taken into account the net effect is negative.

Les mesures de l'effet des dépenses militaires sur l'économie ont eu tendance à s'appuyer sur des modèles inputs-outputs ou des modèles transversaux internationaux plutôt que sur des estimations de séries chronologiques. Nous estimons l'effet des dépenses militaires sur l'investissement, l'emploi et la croissance en France et au Royaume-Uni. Les principaux résultats suggèrent que les dépenses militaires tendent à réduire l'investissement et à augmenter le chômage. Elles ont un effet positif immédiat sur la croissance, mais lorsque les rétroactions du système sont prises en compte, l'effet net est négatif.

Defense spending, economic growth, investment, unemployment Dépenses militaires, croissance, investissement, chômage

\section{INTRODUCTION}

Estimates of the effect of military expenditure on the economy have tended to rely on either input-output or international cross-sections. Aggregate time-series results for individual countries, the primary source of empirical information in most areas of economics, have 
played a comparatively minor role. The purpose of this paper is to investigate, within the context of a small simultaneous model, the light that aggregate time-series data shed on the impact of military expenditure in France and Britain on investment, unemployment and growth.

Time-series estimation has played a minor role in this area for a number of reasons:

1. Most theoretical models used as the basis for specification by the profession do not include an explicit role for military expenditure. Thus it is quite rare for economists concerned to explain macroeconomic phenomena to investigate the impact of military expenditure. There are of course exceptions such as Kormendi, ${ }^{1}$ but relative neglect is the rule.

2. The main interest tends to be on the industrial and regional effects of changes in military expenditure and input-output models are better suited to revealing these. The classic study for the USA is by Leontief et al. ${ }^{2}$ similar exercises are reported for France in Aben, ${ }^{3}$ and for Britain in Dunne and Smith. ${ }^{4}$ Simulations of this sort also tend to suggest that changes in military expenditure, matched by other policy actions which leave the fiscal stance broadly unchanged, have relatively small macroeconomic effects. This might suggest that the macroeffect of military expenditure does not differ much from that of other government demand. However, it might merely be a product of the fact that these models constrain military expenditure to have effects similar to other government demands.

3. Peace-time military expenditures in OECD countries have shown relatively little variance around trend. This means that timeseries estimates of its impact will tend to exhibit large standard errors. Wars have introduced more variance in military expenditure, but call into question the assumptions of structural stability on which time-series estimation is based. In these circumstances international cross-sections provide enough variability for more precise parameter estimation. In studies which do both timeseries and cross-section estimation, such as Smith, ${ }^{5}$ the large dispersion and standard errors of the time-series parameters contrast with the right cross-section estimates. However, the fact that the average time-series estimate matches the cross-section estimate provides some support for interpreting the former as picking up short-run impacts and the latter long-run ones. 
4. Many of the important mechanisms by which military expenditure might influence macroeconomic performance resist quantification. These include technological spin-off; modernisation ethics and social discipline; effects of perceived security on discount rates; and the like. These effects, if present, are attributed to quantified variables in econometric estimation.

Despite these difficulties, it seems worthwhile to attempt a systematic investigation, using a small simultanebus macroeconomic system to estimate the defence expenditure multiplier on growth, unemployment and investment, for France and the UK.

Section II sets out the three-equation theoretical model used for each country; section III reports the estimation results and some diagnostic testing; and section IV summarises the quantitative conclusions and evaluates the strengths and limitations of the approach.

\section{THEORY}

A principal aim of this analysis is to investigate the macroeconomic implications of military expenditure in France and the UK. Specifically, we will focus upon the consequences for investment, unemployment and growth. Previous single-equation studies have highlighted the direct impact of military expenditure, but these direct effects will feed through the macroeconomy interacting with one another. To identify these mechanisms a complete simultaneous equation model is required.

Since the purpose of this exercise is to produce comparative military expenditure multipliers for France and the UK, we have endeavoured to adopt similar model specifications. Comparison is also facilitated if the variables used are commensurable; therefore, where possible, the variables of interest should be unit free, for example as percentages, growth rates or shares. This approach has the added advantage that it is likely to reduce problems of heteroscedasticity (non-constant error variances). The three endogenous variables upon which we will focus are: the share of investment in GDP, the unemployment rate, and the growth rate of GDP. A variety of empirical work has suggested that the major impact of military expenditure is one investment, thus it deserves inclusion. Unemployment should also be examined because of the considerable political controversy surrounding the impact of military expenditure 
upon this important macroeconomic indicator. Lastly, since the growth rate of GDP is the most widely used measure of economic performance, the channels through which it is affected by military expenditure must be assessed. Clearly a more complete model of the macroeconomy would allow for monetary and trade linkages together with a variety of other feedbacks. However, a small model of the sort used here has the advantage that consistent systems estimators can be used, analytical results can be obtained, and the linkages can be easily identified.

\section{Investment}

The equation explaining the share of investment in GDP is,

$$
\dot{i}=a_{0}+a_{1} g+a_{2} m+a_{3} u+a_{4} i_{-i}
$$

where

$$
\begin{aligned}
& i=\text { share of gross fixed capital formation in GDP } \\
& g=\text { growth of constant price (1975) GDP } \\
& m=\text { share of military expenditure in GDP } \\
& u=\text { proportion unemployed }
\end{aligned}
$$

The detailed derivation of this equation is given in Smith, ${ }^{6}$ where it is applied to fourteen countries, including France and the UK, for 1954-73. A priori expectations are that $a_{1}$ and $a_{4}$ will be positive, $a_{2}$ and $a_{3}$ negative.

\section{Unemployment}

The unemployment equation takes the form:

$$
u=b_{0}+b_{1} g+b_{2} m+b_{3} u_{-1}+b_{4} E+b_{5} t
$$

where

$$
\begin{aligned}
& E=\text { growth of exports } \\
& t=\text { time trend }
\end{aligned}
$$

This equation is derived from a partial adjustment labour demand function of Okun's law form, which links unemployment to the 
growth rate of GDP, while allowing the demand factors of military expenditure and export growth to impart differential effects. Further, a time trend has been included to capture the impact of productivity improvements. We expect $b_{2}, b_{3}$ and $b_{5}$ to be positive, while $b_{1}$ and $b_{4}$ should be negative.

\section{GDP Growth}

To explain growth we assume that the full employment level of output is given by a Cobb-Douglas production function:

$$
\tilde{q}=\alpha_{1}+\alpha_{2} f+\alpha_{3} k+p
$$

where the variables are logarithms of: full employment output, $\tilde{q}$; labour force, $f$; capital stock, $k$; and total factor productivity/ technology $p$. In general we use upper-case letters for the variables and lower-case letters for their logarithms.

The $\log$ of actual output, $q$, deviates from $\tilde{q}$, by:

$$
q-\tilde{q}=\beta_{1}(e-l)
$$

where $e$ is the $\log$ of employment and $l$ of measured labour force. Since the rate of unemployment is:

$$
u=\frac{L-E}{L}
$$

thus

$$
e-1=\log (1-u) \approx-u
$$

ignoring higher order terms in the approximation. Substituting (16.5) into (16.4) and then (16.4) into (16.3) gives

$$
q=\alpha_{1}+\alpha_{2} f+\alpha_{3} k+p-\beta_{1} u
$$

Taking first differences yields an equation explaining the growth rate of GDP:

$$
\Delta q=\alpha_{2} \Delta f+\alpha_{3} \Delta k+\Delta p-\beta_{1} \Delta u
$$


Since, $\Delta k$ is roughly the proportionate growth rate in capital stock $K$; and $I=\Delta K+\delta K$, where $I$ is gross investment and $\delta$ is rate of depreciation: then assuming a constant output-capital ratio, $v=Y / K$ :

$$
\Delta k=\Delta K / K=(I-\delta K) / K=v i-\delta
$$

We shall also assume that over the longer run, $\Delta f=n$ a constant. Short-run variations in the size of the labour force will be allowed for by not imposing the first difference restriction on $u$.

Normally the growth rate of total factor productivity, $\Delta p$, is treated as a constant in econometric studies. However, we shall allow it to be determined by an error-correction term, catch-up effects and technological spin-off from military expenditure. The error-correction process removes deviations between GDP and a long-run trend and is modelled as

$$
-\lambda_{1}\left(q_{-1}-\beta_{2} t\right)
$$

where $\beta_{2} t$ measures the long-run path. Second, 'catch-up', that is, international technological convergence to US levels is modelled as:

$$
-\lambda_{2} G_{1-1} \equiv-\lambda_{2}\left[\ln P_{1-1} / \ln \left(P \frac{\text { US }}{1-1}-P_{1-1}\right)\right]
$$

where $P=$ manufacturing productivity.

The rationale for this variable rests upon intuitive notions of international convergence of technology; see Cornwall and Marris. ${ }^{7.8}$ Specifically, it is assumed that the level of manufacturing productivity of a nation converges asymptotically to its target represented by the US productivity level. This US target is selected as it is likely to be a reliable indicator of international best practice. In the jargon of dynamic econometrics, this gap variable is a non-linear errorcorrection mechanism. Further, this term specifies the inherent long-run manufacturing-productivity equilibrium as productive homogeneity. However, such a state is only approached asymptotically over time. The long-run adjustment path is the familiar logistic function, where the target represents the ceiling towards which the adjustment converges (see Martin). ${ }^{9}$.

Finally we shall endeavour to capture technological spin-off effects of military expenditure by including this variable directly as a 
determinant of technological change, $\lambda_{3} m_{t}$. It should be noted that although military expenditure is included because of the spin-off argument, it may also have a Keynesian demand-expansion effect and we cannot distinguish these two mechanisms with this model.

Combining these elements:

$$
\Delta \mathrm{p}=-\lambda_{1}\left(q_{-1}-\beta_{2} l\right)-\lambda_{2} G_{\ell-1}+\lambda_{3} m_{\ell}
$$

and our full model for GDP growth takes the form

$$
\begin{aligned}
& \Delta q_{t} \equiv g_{t}=\alpha_{2} \bar{n}+\alpha_{3}\left(v i_{t}-\delta\right)-\lambda_{1} q_{t}-1 \cdots \\
& \ldots+\lambda_{1} \beta_{2} t-\lambda_{2} G_{t-1}-\beta_{1} \Delta u_{t}+\lambda_{3} m_{t}
\end{aligned}
$$

Removing the first difference restriction on unemployment, the estimating equation takes the form:

$$
\begin{aligned}
& g=c_{0}+c_{1} i+c_{2} u+c_{3} u_{-1}+c_{4} m_{t}+c_{5} q_{-1} \ldots \\
& \ldots+c_{6} t+c_{7} G_{-1}
\end{aligned}
$$

The intercept $c_{0}\left(=\alpha_{2} n-\alpha_{3} \delta\right)$ represents a mixture of effects, : thus we have no prior expectations concerning its sign. A priori $c_{1}\left(=\alpha_{3} v\right), c_{3}\left(=\beta_{1}\right)$ and $c_{6}\left(=\lambda_{1} \beta_{2}\right)$ should be positive, as should $c_{4}$ $\left(=\lambda_{3}\right)$ if military spin-off contributes to growth, while $c_{2}\left(=-\beta_{1}\right)$, $c_{5}\left(=-\lambda_{1}\right)$ and $c_{7}\left(=\lambda_{2}\right)$ should be negative. Note, if the specification of the model is correct, $c_{2}$ and $c_{3}$ should be of roughly equal magnitude and opposite in sign.

\section{Simultaneous Equation Systems}

The simultaneous system we propose to study is composed of the investment, unemployment and growth equations derived above (equations $16.1,16.2$ and 16.9 respectively). The complete system is thus:

$$
\begin{aligned}
& i=a_{0}+a_{1} g+a_{2} m+a_{3} u+a_{4} i_{-1} \\
& u=b_{0}+b_{1} g+b_{2} m+b_{3} u_{-1}+b_{4} E+b_{5} t \\
& g=c_{0}+c_{1} i+c_{2} u+c_{3} u_{-1}+c_{4} m+c_{5} q_{-1} \ldots \\
& \cdots+c_{6} t+c_{7} G_{-1}
\end{aligned}
$$


The growth equation is just identified, the other two overidentified. The impact multipliers of military expenditure on the three endogenous variables are:

$$
\begin{aligned}
& \frac{\partial g}{\partial m}=\pi_{3}=\frac{c_{1} a_{2}+c_{1} a_{3} b_{2}+b_{2} c_{2}+c_{4}}{1-c_{1} a_{1}-c_{1} a_{3} b_{1}-c_{2} b_{1}} \\
& \frac{\partial u}{\partial m} \equiv \pi_{2}=b_{1} \pi_{3}+b_{2} \\
& \frac{\partial i}{\partial m} \equiv \pi_{1}=\left(a_{1}+a_{3} b_{1}\right) \pi_{3}+a_{2}+a_{3} b_{2}
\end{aligned}
$$

If the system is stable, that is, with roots which lie within the unit circle, the long-run multipliers from the final form give the effect of military expenditure when all the dynamic adjustment processes have worked through the system.

- The long-run multipliers are:

$$
\begin{aligned}
& \partial g / \lambda m \equiv \phi_{3}=\frac{a_{2} c_{1}\left(1-b_{3}\right)+b_{2} a_{3} c_{1}+b_{2}\left(c_{2}+c_{3}\right)\left(1-a_{4}\right)+c_{4}\left(1-a_{4}\right)\left(1-b_{3}\right)}{\left(1-a_{4}\right)\left(1-b_{3}\right)-a_{1} c_{1}\left(1-b_{3}\right)-b_{1} a_{3} c_{1}-b_{1}\left(c_{2}+c_{3}\right)\left(1-a_{4}\right)} \\
& \lambda u / \partial m \equiv \phi_{2}=\frac{1}{1-b_{3}}\left\{b_{1} \phi_{3}+b_{2}\right\} \\
& \text { itilimm } \equiv \phi_{1}=\frac{1}{\left(1-a_{4}\right)\left(1-b_{3}\right)}\left\{\left[a_{1}\left(1-b_{3}\right)+a_{3} b_{1}\right] \phi_{3}+b_{2} a_{3}+a_{2}\left(1-b_{3}\right)\right\}
\end{aligned}
$$

It could be argued that the lagged effects which arise from the level of GDP, $q_{-1}$, should also be allowed for (when calculating these final-form multipliers); but, given our interpretation of this variable (in terms of an error-correction process), this does not seem appropriate. 


\section{ECONOMETRIC RESULTS}

The system described in the previous section was estimated over the period 1954-82, for France and the UK by Three Stage Least Squares (3SLS). Definitions of the variables and results are given in the appendix to this chapter. A single system was estimated for the two countries together to allow for non-zero disturbance co-variances as a result of international influences to which both countries were subject.

Initially, some investigations of the specification was carried out using Ordinary Least Squares (OLS). This indicated that investment had a negative effect on growth in the French equation, and since this conflicts with standard economic theory, a zero coefficient was imposed. Inspection of the results also suggested that 1954 and 1955 were outliers and this was allowed for using a dummy variable for those two years denoted D55. This effect may be associated with the military activity at the time, post-Korea for the UK and Indo-China for France.

The regression results are shown in appendix Tables 16.1A-16.1C. : The investment and unemployment equations fit well in both countries, the growth equation less well, but this is not unusual; there are severe difficulties in explaining growth. The system was subjected to a variety of diagnostic tests, which are described and reported in the appendix. Apart from some suggestion of higher-order effects in the unemployment equation there is no indication of serial correlation. Structural stability is accepted for France in all six tests. For the UK, there is an indication that the growth equation may have shifted in 1959 and the unemployment equation in 1973, but in both cases the null hypothesis of stability can be accepted at the 1 per cent level.

Except for the zero coefficient on investment in France, which was imposed, all the structural coefficients estimated have their expected signs. As the theory predicts, the coefficients of current and lagged unemployment in the growth equation have opposite signs. The hypothesis that the unemployment coefficients are equal with opposite signs can be accepted for the UK $(F=0.072)$ but is rejected for France $(F=4.39)$.

Overall, the differences between the estimates for the two countries are not large. Equality of the coefficients in the British and French investment equations can be accepted at the 5 per cent level $(F=1.39)$ and in the unemployment equations at the 1 per cent level $(F=2.73)$. Even in the growth equation where equality is rejected at 
the 1 per cent level, the test statistic $(F=8.64)$ is not that large given the extreme nature of the hypothesis tested.

The narrower hypothesis - that the coefficients of military expenditure are the same in both countries - can be accepted in all three equations at the 5 per cent level. Thus there is no evidence from these results that the effect of military expenditure differs between France and the UK. In both countries the structural coefficients indicate that military expenditure is associated with reduced investment, increased unemployment and higher growth in the first instance; though only the French investment and unemployment coefficient are significant.

The major problem with these results is that the UK estimates imply unstable dynamic behaviour. Whereas for France the roots of -0.59 and -0.91 indicate stability, those for the UK of -0.825 and -2.42 indicate explosive divergence. The UK instability seems to arise primarily from the coefficient of 1.01 on the lagged dependent variable in the unemployment equation. When the system is unstable, the long-run multipliers are undefined because the system does not return to an equilibrium after an exogenous shock.

The multipliers can be calculated either from the 'restricted reduced form', which is derived from the estimated structural equations, or the 'unrestricted reduced form', obtained by the regression of the endogenous variables on the whole set of predetermined variables. The estimates from the restricted reduced form will be more efficient if the over-identifying restrictions imposed on the structural equations are correct. There are five over-identifying restrictions on the UK system and six on the French. Since the failure of stability casts doubt on the specification, the unrestricted reduced form was also estimated and the results are given in the appendix, Tables $16.2 \mathrm{~A}$ and $16.2 \mathrm{~B}$.

In comparing the two sets of estimates, it is noticeable that the estimated standard errors of regression (SER) are very similar between structural and reduced-form equations except in the case of UK unemployment, where the reduced form SER is considerably smaller. In general, the estimated coefficients of military expenditure are more precisely determined in the reduced-form estimates than in the structural estimates. The military expenditure coefficients are significantly different from zero at the 5 per cent level in all three UK equations, and all except the investment equation for France. This is exactly the reverse of the pattern in the structural coefficients. The differences between the reduced-form and structural estimates could be exploited through the use of a variety of statistical tests. For 
instance, conditional on the exogeneity assumptions, the overidentifying restrictions could be tested; or, conditional on the overidentifying restrictions, exogeneity could be tested. However, the small-sample properties of these tests are poor, and given the degree of prior belief in the specifications, it is not clear how revealing they would be.

The results are summarised in Table 16.1. This gives the various estimates of the coefficients of military expenditure. The structural coefficients measure the direct effect; the impact multipliers the effect in the current year, once allowance has been made for the simultaneous feedbacks through the endogenous variables. The long-run multipliers allow for the total effect once the dynamic responses through lagged endogenous variables have been allowed for. Long-run multipliers are not given for the UK because the

Table 16.1 The impact of military expenditure

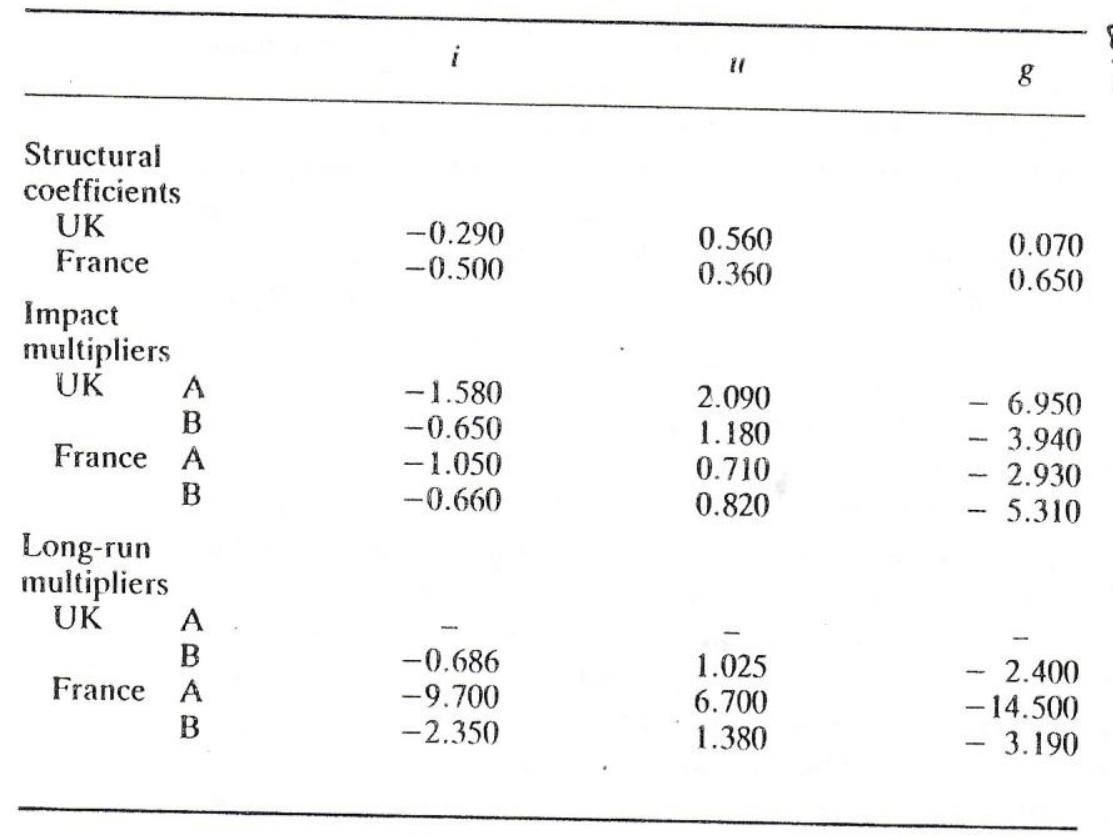

Notes: A From restricted reduced form

B From unrestricted reduced form

$i$ share of gross fixed capital formation in GDP

$u$ proportion of labour force unemployed

$g$ The change in the logarithm of constant price GDP 
structural system is unstable. The unrestricted reduced form is stable for both countries, with convergent cyclical solution for France.

Cross-section results (for example, Smith) ${ }^{10}$ suggest that military expenditure has a strong negative effect on investment; a small direct positive effect on growth, but a negative total effect on growth when allowance is made for the linkage through investment; and no clear relation with unemployment. The results in Table 16.1 are broadly consistent with this pattern as far as growth and investment are concerned; but the negative effects of military expenditure seem implausibly large by comparison with cross-section estimates. The result - that higher military expenditure tends to be associated with higher unemployment - is not in accord with the cross-section results.

It should be remembered that all government policy multipliers are sensitive to the Lucas critique. Large changes in military expenditure are likely to change the patterns of private sector behaviour and thus the coefficients on which the estimates are based. This is the reason that wartime observations are usually regarded as being the product of a different regime. It is unlikely, however, that this would be a serious problem for inferences about the effect of changes of the same order of magnitude as those observed over the sample period.

\section{CONCLUSION}

Econometric results always have to be treated with some caution, but the quantitative conclusion suggested by these estimates is that military expenditure tends to be associated with reduced investment and increased unemployment, and that these damaging effects are magnified when the system feedbacks are taken into account. With respect to growth: the direct effect of military expenditure, whether through technological spin-off or demand expansion, is positive, but this is more than offset by the negative indirect effects through invesiment and unemployment. Thus the net effect is for higher military expenditure to be associated with lower growth. These conclusions are broadly in line with previous empirical results. Interestingly there was no significant difference between the direct effects of military expenditure in Britain and France.

These results can be regarded as a useful contribution to a general strategy of investigating the effects of military expenditure from as many different perspectives as possible. This is the strategy of 
methodological pluralism advocated in Fontanel and Smith. "The results in this paper can be regarded as complementary to those in Aben and Smith. ${ }^{12}$ The two studies try to bracket the question by doing both aggregate time-series analysis and disaggregated input-output analysis. However, the questions about the relative advantages of aggregate time-series analysis against other methods of investigation remain.

Although the results are useful, they have obvious limitations. They are dependent on the particular theoretical model used as a framework for estimation, and other models might produce different results. In particular the effect of variables excluded from the model will be attributed to military expenditure, to the extent that they are correlated with it. Clearly, there is no shortage of potential excluded variables; but testing for their inclusion raises the familiar difficulties of specification searching, multicollinearity and interpretative complexity. The use of a single aggregate variable, the share of military expenditure in output, is very limited. The presence of conscription, the balance between personnel and equipment, the use of domestic or imported weapons, and all the other details of defence posture will have a differential effect. The aggregate time-series results can only capture simple empirical regularities. Finally, the degree of aggregation means that relatively little is revealed about the detailed transmission mechanisms involved. Nonetheless, despite these limitations, the results provide a little more information on the impact of military expenditure.

\section{APPENDIX}

Variables

Unless otherwise specified the data are taken from OECD National Accounts Statistics, or national sources.

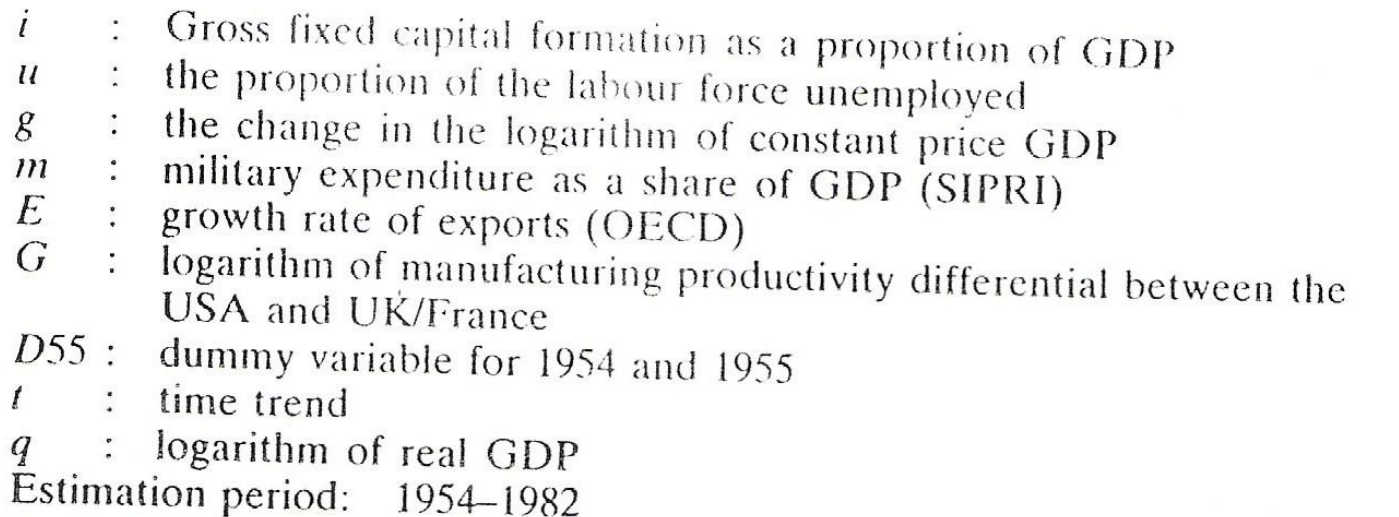




\section{Statistics}

$\bar{R}^{2}$ is the coefficient of determination corrected for degrees of freedom. With 3SLS estimates the interpretation of this statistic is not straightforward.

$S E R$ is the Standard Error of Regression.

$D W$ is the Durbin Watson Statistic which tests for First Order Serial Correlation.

$L M F(\quad)$ are small sample versions of a Lagrange Multiplier test for higher order serial correlation. They are obtained by regressing the equation residuals on 4 and 2 lagged residuals plus equation regressors. The $F$ statistic given (with degrees of freedom in parentheses) tests that the coefficients of the lagged residuals are zero.

$S S F(\quad)$ are tests for structural stability. The sample is split at the year given and an $F$ statistic calculated for the hypothesis that the coefficients are the same in the two subperiods. The 1959 break is suggested by the returin to convertibility by European countries, the formation of the EEC, and in the case of France the change from old to new SNA. The oil price increase and the demise of the Bretton-Woods system suggest the 1973 break.

? For the $3 S L S$ results, $F$ statistics are given to test the hypotheses:

1. The coefficients of military expenditure are the same in each country;

2. All the coefficients in the equation are the same. 
Table 16.1A Three Stage Least Squares results: investment

\begin{tabular}{lcrcr}
\hline & \multicolumn{2}{c}{ UK } & \multicolumn{2}{c}{ France } \\
\hline Const & 0.056 & $(1.47)$ & 0.12 & $(2.72)$ \\
$g_{t}$ & 0.147 & $(3.47)$ & 0.133 & $(1.77)$ \\
$u_{t}$ & -0.13 & $(-2.51)$ & -0.23 & $(-2.08)$ \\
$i_{-1}$ & 0.79 & $(6.25)$ & 0.59 & $(4.62)$ \\
$D 55$ & 0.0003 & $(0.06)$ & -0.005 & $(-1.16)$ \\
$m_{f}$ & -0.29 & $(-1.18)$ & -0.50 & $(-2.4)$ \\
$\bar{R}^{2}$ & 0.9040 & & 0.9350 & \\
SER $\times 100$ & 0.427 & & 0.390 & \\
$D W$ & 2.199 & & 1.60 & \\
LMF(4) & 1.16 & $(4.19)$ & 1.06 & $(4.19)$ \\
LMF(2) & 1.88 & $(2.21)$ & 0.65 & $(2.21)$ \\
SSF $(1959)$ & 0.226 & $(6.18)$ & 1.69 & $(6.18)$ \\
SSF $(1973)$ & 2.28 & $(9.15)$ & 2.64 & $(9.15)$ \\
& & & &
\end{tabular}

Cross-couniry Parameter Equality Tesis

1. $M(\mathrm{UK})=M(\mathrm{FC}) \quad F_{0}(1,131)=0.630$

2. $a_{i}(\mathrm{UK})=a_{i}(\mathrm{FC}) \quad F_{0}(6,131)=1.39$

Note: 1 statistics for coefficients and degrees of freedom for tests are given in parentheses. 
Table 16.1B Three Stage Least Square results: unemployment

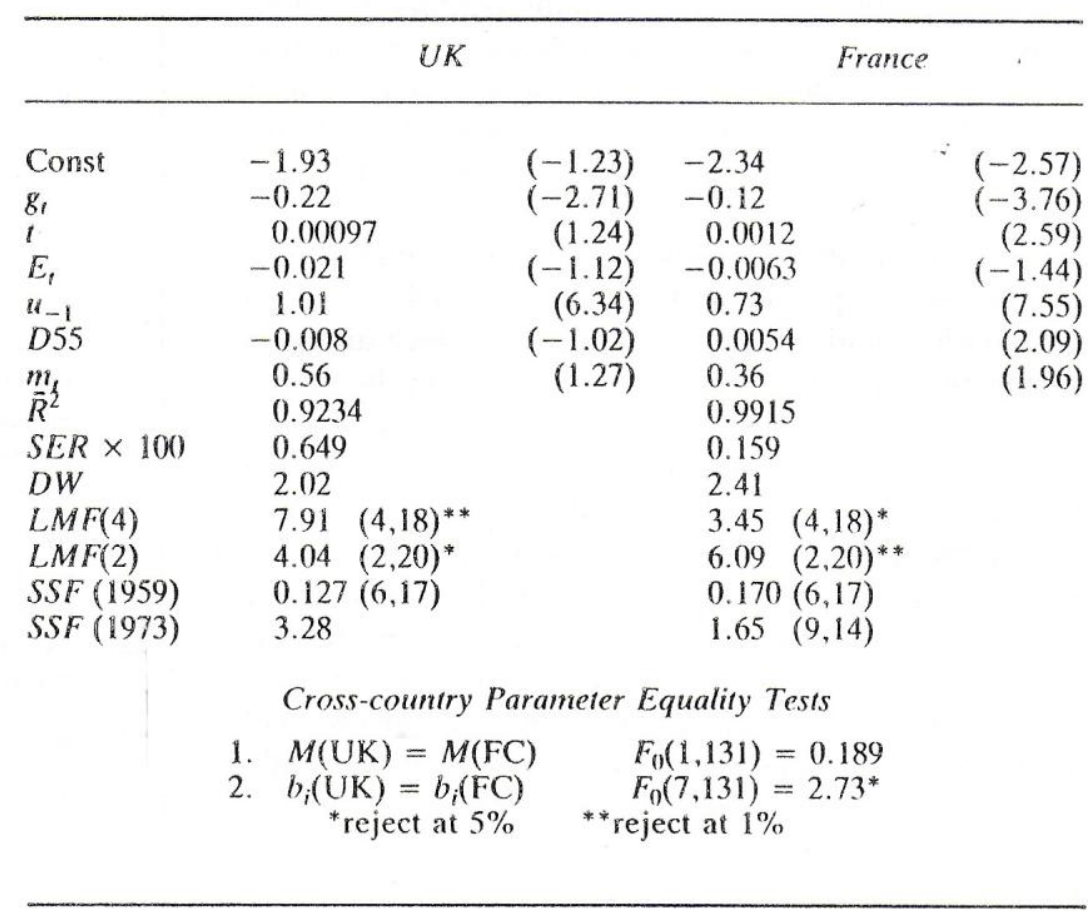


Table 16.1C Three Stage Least Square: GDP growth

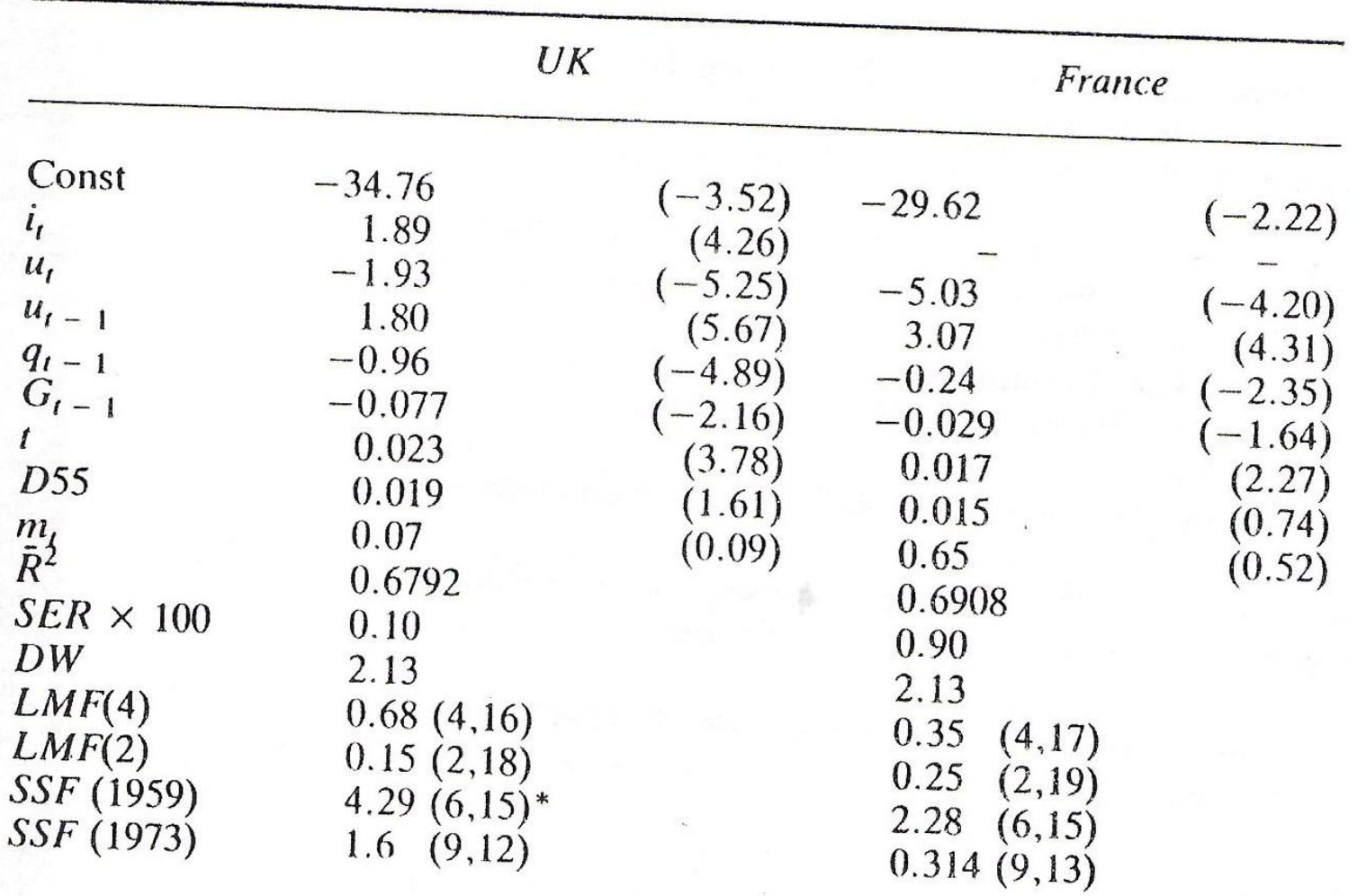

\section{Cross-country Parameter Equality Tests}

$\begin{array}{lll}\text { 1. } & M(\mathrm{UK})=M(\mathrm{FC}) & F_{0}(1,131)=0.198 \\ \text { 2. } & C_{i}(\mathrm{UK})=C_{i}(\mathrm{FC}) & F_{0}(9,131)=8.644^{* *} \\ & { }^{*} \text { reject at } 5 \% & \text { ** reject at } 1 \%\end{array}$ 
Table 16.2A Unrestricted reduced form

\begin{tabular}{lccc}
\hline & \multicolumn{3}{c}{$U K$} \\
& $i$ & $u$ & $g$ \\
& & & -3.935 \\
$E$ & -0.646 & 1.184 & $(-4.8)$ \\
& $(-2.3)$ & $(3.7)$ & 0.218 \\
$t$ & 0.040 & -0.062 & $(4.4)$ \\
& $(2.4)$ & $(-3.2)$ & -0.008 \\
$D 55$ & -0.007 & 0.013 & $(-1.5)$ \\
& $(4.0)$ & $(6.8)$ & 0.035 \\
$q_{-1}$ & -0.001 & -0.005 & $(2.5)$ \\
& $(-0.3)$ & $(-1.0)$ & 0.007 \\
$G_{-1}$ & 0.235 & -0.401 & $(0.04)$ \\
& $(4.0)$ & $(-5.9)$ & -0.225 \\
$u_{-1}$ & -0.024 & 0.040 & $(-4.1)$ \\
$i_{-1}$ & $(-1.32)$ & $(1.9)$ & 0.631 \\
Const & 0.099 & 0.32 & $(1.2)$ \\
$\bar{R}^{2}$ & $(0.54)$ & $(1.5)$ & -1.300 \\
$D W$ & 0.200 & 0.71 & $(-2.0)$ \\
$S E R \times 100$ & $(0.925)$ & $(2.8)$ & 15.35 \\
& 10.73 & -21.51 & $(1.91)$ \\
& $(4.0)$ & $(-6.94)$ & 0.7115 \\
\hline & 0.9099 & 0.9599 & 2.34 \\
& 2.16 & 1.75 & 1.182 \\
& 0.396 & 0.457 & \\
\hline
\end{tabular}


Table 16.2B Unrestricted reduced form

\begin{tabular}{|c|c|c|c|}
\hline & $i$ & France & $g$ \\
\hline$m 8$ & -0.655 & 0.818 & -5.305 \\
\hline & $(-1.4)$ & $(3.7)$ & $(-4.4)$ \\
\hline t & 0.018 & -0.008 & -0.011 \\
\hline & $(1.1)$ & $(-1.1)$ & $(-0.3)$ \\
\hline$t$ & -0.001 & 0.003 & 0.007 \\
\hline & $(-0.2)$ & $(1.8)$ & $(0.7)$ \\
\hline D55 & -0.008 & 0.015 & -0.080 \\
\hline & $(-1.1)$ & $(4.25)$ & $(-4.2)$ \\
\hline $9-1$ & 0.003 & -0.021 & 0.260 \\
\hline & $(0.1)$ & $(-0.7)$ & $(-1.7)$ \\
\hline$G_{-1}$ & 0.001 & 0.010 & 0.106 \\
\hline & $(0.1)$ & $(1.8)$ & $(-3.6)$ \\
\hline$u_{-1}$ & -0.211 & 0.577 & -0.248 \\
\hline & $(-0.5)$ & $(3.0)$ & $(-0.2)$ \\
\hline$I_{-1}$ & 0.595 & 0.099 & -1.047 \\
\hline & $(3.3)$ & (1.2) & $(-2.3)$ \\
\hline Const & 1.6 & -5.7 & -9.1 \\
\hline $\bar{D} 2$ & $(0.3)$ & $(-2.0)$ & $(-0.6)$ \\
\hline $\begin{array}{l}R^{2} \\
D W\end{array}$ & 0.9472 & 0.9885 & 0.6273 \\
\hline $\begin{array}{l}D W \\
S F R \times 100\end{array}$ & 1.56 & 2.16 & $1.80^{\circ}$ \\
\hline$S E R \times 100$ & 0.381 & 0.179 & 0.975 \\
\hline
\end{tabular}




\section{Notes and References}

* We are grateful for financial support from the Centre Nationale de la Recherche Scientifique and the Economic and Social Research Council for a collaborative study on the defence efforts in France and the UK.

1. Kormendi, R. C. 'Government Debt, Government Spending and Private Sector Behaviour', American Economic Review, vol. 73, no. 5 (December, 1983) pp. 994-1000.

2. Leontief, W. ef al. 'The Economic Impact - Industrial and Regional - of an Arms Cut', Review of Economics and Statistics, vol. 47. (August 1965) pp. 217-41.

3. Aben, J. 'Désarmement, Activité et Emploi' Défense Nationale, (mai 1981) pp. 105-23.

4. Dunne, J. P. and Smith, R. 'The Economic Consequences of Reduced Military Expenditure', Cambridge Journal of Economics (Sepiember 1984).

5. Smith, R. P. 'Military Expenditure and Investment in OECD Countries 1954-1973'. Journal of Comparative Economics, vol. 4, 1980, pp. 19-32.

6. Smith (see note 5).

7. Cormwall, J. 'Diffusion, Convergence and Kaldor's Laws', Economic Journal, 86 (June 1976) pp. 307-14.

8. Marris, R. 'How Much of the Slow Down was Catch-up?' in RCO Matthews (ed.), Slower Growth in the Western World (London: National Institute of Economic and Social Research, 1982).

9. Martin, S. 'Convergence as an Empirical Determinant of Long-run Productivity Growth', Birkbeck Discussion Paper no. 158 (1984).

10. Smith, R. P. 'Military Expenditure and Capitalism: A Reply', Cambridge Journal of Economics, Vol. 2 (Sep 1978) 299-304.

11. Fontanel, J. and Smith, R. 'Analyse économique des dépenses militaire', Stratégique, no. 3, 1985, pp. 73-116 and Fontanel, J., 'Formalised Studies and Econometric Analysis of the Relationship between Military Expenditure and Economic Development', United Nations. 1980.

12. Aben, J. and Smith, R. P. 'Defence and Employment in the UK and France' (this volume). 


\section{Bibliographie}

Aben, J. (1981), Désarmement, Activité et Emploi, Défense Nationale, Mai.

Aben, J., Smith, R.P. (1987), Defence and Employment in the UK and France, Peace, Defence and Economic Analysis", Mac Millan, London

Cornwall, J. (1976), Diffusion, Convergence and Kaldor's laws, Economic Journal, June, 86.

Dunne, J.P., Smith, R. (1984), The Economic Consequences of Reduced Military Expenditure, Cambridge Journal of Economics, September.

Fontanel, J. (1980), Etudes formalisées et analyses économétriques du couple dépenses militaires-développement économique. Les exemples d'un pays développé, la France et d'un pays en voie de développement, le Maroc. Rapport pour le Groupe d'Experts des Nations Unies sur le "Désarmement pour le Développement". Mars 1980

Fontanel, J. (1982), Military expenditures and economic growth (France, Morocco), United Nations Copyright, 1982 (160 pages).

Fontanel, J., Smith, R. (1985), L'effort économique de défense, Ares, Défense et Sécurité, Supplément n 4 - Novembre 1985

Fontanel, J. (1985), L'économie des armes, La Découverte, Paris.

Fontanel, J., Smith, R. (1985), Analyse économique des dépenses militaires, Stratégique, ${ }^{\circ} 3$.

Kormandi, R.C. (1983), Government Debt, Government Spending and Private Secctor Behaviour, American Economic Review, Vol 73, n5. December.

Leontief, W and al. (1965), The Economic Impact-Industrial and Regional- of an Arms Cut, Review of Economics and Statistics, Vol. 47? August.

Marris, R. (1982), Howmuch of the Slow Down was Catch-up, in Slower Growth in the Western World (Matthews, ed), National Institute of Econoimic and Social Research, London.

Martin, S. (1984), Convergence as an Empirical Dezterminant of Longrun productivity Growth, Birkbeeck Discussion Paper, ${ }^{\circ} 158$.

Smith, R.P. (1978), Military Expenditure and Capitalism. Cambridge Journal of Economics, Vol.2, September.

Smith, R.P. (1980), Military Expenditure and Investment in OECD Countries 1954-1973. Journal of Comparative Economics, Vol. 4. 